\title{
Comparative study of sublingual and vaginal misoprostol in second trimester induced abortion
}

\author{
Sangeeta Raman Jogi*
}

Associate Professor, Department of Obstetrics and Gynaecology, Chhattisgarh Institute of Medical Sciences, Bilaspur495001, Chhattisgarh, India

Received: 10 August 2015

Accepted: 15 August 2015

\section{*Correspondence:}

Dr. Sangeeta Raman Jogi,

E-mail: raman.jogi@yahoo.com

Copyright: (c) the author(s), publisher and licensee Medip Academy. This is an open-access article distributed under the terms of the Creative Commons Attribution Non-Commercial License, which permits unrestricted non-commercial use, distribution, and reproduction in any medium, provided the original work is properly cited.

\begin{abstract}
Background: To recognize an effective Misoprostol only regime and to compare the efficacy, safety and acceptability of sublingual and vaginal Misoprostol for the termination of second trimester of pregnancy.

Methods: The study was a prospective randomized trial. Women attending OPD from January2012 to December 2013, for medical abortion between gestational ages 13-20 weeks were screened, selected and divided in to two groups. Group-A received misoprostol $400 \mu \mathrm{g}$ then $200 \mu \mathrm{g}$ sublingually 3 hourly, Group-B received misoprostol 400 $\mu \mathrm{g}$ then $200 \mu \mathrm{g}$ vaginally 3 hourly. They were observed for 24 hours. Main outcomes were induction-abortion interval, dose required, success rate and side effects and comfort to the route of administration.

Results: Mean induction-abortion interval was $9.28 \pm 5.824$ hours, 95\% CI: 7.62-10.94in sublingual misoprostol group and $13.68 \pm 6.179$ hours, 95\% CI: 11.92-15.44 in vaginal group. Mean dose required for abortion was $948 \pm$ $389.264 \mu \mathrm{g}, 95 \% \mathrm{CI}: 837.37-1058.63$ in sublingual and $1248 \pm 415.142 \mu \mathrm{g}$, 95\% CI: 1,130.02-1,365.98in vaginal group. Success rate was $98 \%$ and $94 \%$, respectively in two groups. The differences were statistically significant. Comfort to the route of administration was $90 \%$ in sublingual and $60 \%$ in vaginal group.

Conclusions: Both sublingual and vaginal routes of Misoprostol are equally effective, safe, inexpensive and acceptable method. Sublingual route is better and preferred by women.
\end{abstract}

Keywords: Misoprostol, Second trimester pregnancy termination, Sublingual route, Vaginal route, Abortion, Midtrimester Abortion

\section{INTRODUCTION}

Abortion is defined as termination of pregnancy before the period of viability, which occurs at 20 weeks of gestation and the foetus weighing $500 \mathrm{~g}$. About 40-60 million abortions occur per year globally. Medical abortion is a safe alternative to surgical methods. MTP was legalized in India in 1971. ${ }^{1}$ Estimate indicate that 46 million pregnancies are voluntarily terminated each year, 26 million legally and 20 million outside the legal system. $^{2}$ Various management protocols have been used for second trimester pregnancy termination. These includes surgical techniques (D\&E) and medical approaches such as intra-amniotic prostaglandin (PG) $\mathrm{F}_{2-}$ $\alpha$ instillation, $\mathrm{PGE}_{2}$ vaginal suppositories, $\mathrm{PGE}_{2}$ and high-dose oxytocin. ${ }^{3}$

All these methods require hospitalization and have disadvantage of surgical trauma and anaesthetic complication. $\mathrm{PGE}_{1}$ analogue, misoprostol, originally used for the treatment of peptic ulcer, has been found to have uterotonic effect as well and is used for termination of pregnancy for great success. Chemical formula of misoprostol is $\mathrm{C}_{22} \mathrm{H}_{38} \mathrm{O}_{5}$ or $( \pm)$-methyl (13E)-11, 16dihydroxy-16 methyl-9-oxo-prost-13-eonate. Misoprostol is available as 100 and $200 \mu \mathrm{g}$ tablets and can be used orally, vaginally and rectally. It is cheap, stable at room temperature, does not need refrigeration and is associated with few side effects. ${ }^{4-5}$ 
The present study had been undertaken to assess the efficacy and safety of Misoprostol by sublingual route as compared to vaginal route for induction of second trimester termination of pregnancy.

\section{METHODS}

It was a prospective randomized trial carried out in Dept. of Obstetrics and Gynecology, Chhattisgarh Institute of Medical Sciences from January 2012 to December 2013. All the cases coming to the Dept. Of Obstetrics and Gynecology for second trimester termination of pregnancy (13-20 weeks) were screened for inclusion in the study. A detailed history regarding duration of amenorrhea, gravidity, parity, previous spontaneous or induced abortions and medical diseases was recorded. General and systemic examination was done. Vaginal examination was done to assess the duration of pregnancy and to rule out any pelvic pathology. The gestational age was determined by menstrual history and vaginal examination. Sonography was done if required. Then routine investigations like hemogram, BT, CT, blood sugar, urine examination, VDRL, sickling test, serum creatinine and HIV were done. Cases with respiratory tract disease, organic heart disease, diabetes mellitus, renal disease, uterine scar, pelvic pathology, uterine anomalies, hemorrhagic disorder, jaundice, severe anemia and allergy to prostaglandins were excluded from the study.

After taking an informed consent, cases were divided into two groups.

- Group A ( $\mathrm{n}=50): 400 \mu \mathrm{g}$ then $200 \mu \mathrm{g}$ misoprostol sublingually 3 hourly.

- Group B ( $=50): 400 \mu \mathrm{g}$ then $200 \mu \mathrm{g}$ misoprostol vaginally 3 hourly.
In Group A, induction was carried out on inpatient basis by giving $400 \mu \mathrm{g}$ sublingually, there after $200 \mu \mathrm{g}$ sublingually 3 hourly till abortion. In Group B, induction was carried out on inpatient basis by inserting $400 \mu \mathrm{g}$ misoprostol tablets into posterior fornix, keeping the patient strictly in bed for half an hour. There after $200 \mu \mathrm{g}$ tablets were inserted intravaginally every 3 hourly until abortion. Time of onset of contraction, bleeding, pain, cervical dilatation, expulsion of fetes including placenta and membrane were looked for. All vital parameters were closely monitored and side effects if any were symptomatically managed. They were kept under observations for two hours after abortion. Patients were discharged with the advice to come for follow-up after two weeks or earlier if necessary. The data was entered and analyzed through software program SPSS (Statistical Package for the Social Sciences) for statistical analysis. The results were represented as mean and standard deviation. The mean induction abortion interval and mean dose required were analyzed by standard error of difference between two means. Success rate and side effects due to different routes of administration were analyzed by their percentage and compared by chi-square test.

\section{RESULTS}

Majority of our patients were married, of 20-30 years of age (Table 1). Forty-nine (98\%) women aborted within 24 hours in sublingual misoprostol group as compared to $47(94 \%)$ in vaginal group. In majority of women pain started within two hours (mean $3.5 \pm 2.33$ ) in sublingual misoprostol group as compared to (mean $3.9 \pm 2.46)$ the vaginal group. Vaginal bleeding started within 4-6 hours (mean $5.26 \pm 2.9$ ) in the sublingual misoprostol group as compared to (mean $6.29 \pm 2.33$ ) the vaginal group.

Table 1: Patients' characteristics.

\begin{tabular}{|lll|}
\hline Variables & Sublingual group & Vaginal group \\
\hline Married & 46 & 45 \\
\hline Unmarried & 04 & 05 \\
\hline Mean age in years & $22.16 \pm 3.228$ & $22.50 \pm 3.541$ \\
\hline Mean weight in $\mathrm{kg}$ & $45.18 \pm 7.558$ & $45.88 \pm 7.644$ \\
\hline Mean height in cm & $148.68 \pm 8.558$ & $150.80 \pm 10.690$ \\
\hline Mean gravidity & $3.28 \pm 1.443$ & $3.66 \pm 1.560$ \\
\hline Mean GA in weeks & $16.72 \pm 2.356$ & $16.78 \pm 2.332$ \\
\hline
\end{tabular}

GA: Gestational age

The mean induction interval was $9.28 \pm 5.824$ hours, $95 \%$ CI: 7.62-10.94 in sublingual misoprostol group as compared to $13.68 \pm 6.179$ hours $95 \% \mathrm{CI}: 11.92-15.44$ in vaginal group. It was decreased with increase in gravidity. It was inversely proportionate to the gravidity (Table 2).
The mean dose of misoprostol $948.00 \pm 389.264 \mu \mathrm{g}(95 \%$ CI 837.37-1058.63) in sublingual misoprostol group was much less as compared to $1,248.00 \pm 415.142 \mu \mathrm{g}(95 \% \mathrm{CI}$ $1,130.02-1,365.98)$ in vaginal group. Misoprostol requirement and induction abortion interval were decreased with increasing gestational age (Table 3). 
Table 2: Gravidity, induction-abortion interval and mean dose of misoprostol.

\begin{tabular}{|c|c|c|c|c|}
\hline \multirow{2}{*}{ Gravidity } & \multicolumn{2}{|c|}{ Mean induction-abortion interval (hours) } & \multicolumn{2}{|c|}{ Mean dose of misoprostol ( $\mu \mathrm{g})$} \\
\hline & Sublingual & Vaginal & Sublingual & Vaginal \\
\hline 1 & $20 \pm 1.414$ & $23.83 \pm 1.472$ & $1,666.67 \pm 103.280$ & $1,900 \pm 109.545$ \\
\hline 2 & $4.89 \pm 1.764$ & $19.89 \pm 1.453$ & $1,311.11 \pm 105$ & $1,688.89 \pm 105.409$ \\
\hline 3 & $8.80 \pm 1.740$ & $13.80 \pm 1.935$ & $920 \pm 126.491$ & $1,266.67 \pm 97.590$ \\
\hline 4 & $5 \pm 0.707$ & $10.11 \pm 0.928$ & $44.44 \pm 88.192$ & $1,000 \pm 00$ \\
\hline 5 & $3.43 \pm 0.535$ & $6.71 \pm 1.113$ & $4,250 \pm 100.0$ & $600 \pm 00$ \\
\hline 6 & $2.25 \pm 0.500$ & $4.25 \pm 0.500$ & $4,250 \pm 100.0$ & $1,248 \pm 415.142$ \\
\hline Total & $9.28 \pm 5.824$ & $13.68 \pm 6.179^{*}$ & $948 \pm 389.264$ & $1,248 \pm 415.142$ \\
\hline
\end{tabular}

*Difference between the two mean is 3.9. I.e. more than three times the SE which is highly significant?

Table 3: Gestational age, induction-abortion interval and mean dose of misoprostol.

\begin{tabular}{|c|c|c|c|c|}
\hline \multirow{2}{*}{ Gravidity } & \multicolumn{2}{|c|}{ Induction Abortion Interval (Hours) } & \multicolumn{2}{|c|}{ Mean Dose of Misoprostol ( $\mu \mathrm{g})$} \\
\hline & Sublingual & Vaginal & Sublingual & Vaginal \\
\hline 13 & $20.40 \pm 1.140$ & 24.1581 & $1,680 \pm 109.545$ & $1920 \pm 109.545$ \\
\hline 14 & $16.50 \pm 1.049$ & $21.33 \pm 1.033$ & $1,433.33 \pm 81.650$ & $1,766.67 \pm 81.650$ \\
\hline 15 & $12.43 \pm 1.272$ & $17.71 \pm 1.113$ & $1,142.86 \pm 97.590$ & $1,514.29 \pm 106.904$ \\
\hline 16 & $9.17 \pm 0.753$ & $14.17 \pm 1.169$ & $966.67 \pm 81.650$ & $1,266.67 \pm 103.280$ \\
\hline 17 & $7.17 \pm 0.753$ & $12 \pm 0.00$ & $800 \pm 000$ & $1,200 \pm 000$ \\
\hline 18 & $5.50 \pm 0.577$ & $11 \pm 00$ & $700 \pm 115.470$ & $1,000 \pm 000$ \\
\hline 19 & $4.38 \pm 0.518$ & $8.75 \pm 1.035$ & $600 \pm 00$ & $825 \pm 103.510$ \\
\hline 20 & $2.63 \pm 0.518$ & $5.13 \pm 1.126$ & $525 \pm 103.510$ & $675 \pm 103.510$ \\
\hline Total & $9.28 \pm 5.824$ & $13.68 \pm 6.179$ & $948 \pm 389.264$ & $1,248 \pm 415.142^{*}$ \\
\hline
\end{tabular}

*Difference between the two mean is 4.8 i.e. more than 3 times of SE and is highly significant

Abortion was considered to be successful, if there was expulsion of fetus with or without expulsion of placenta occurring within 24 hours of insertion of first dose. Success rate was $98 \%$ for sublingual group and $94 \%$ for vaginal group. A significant observation was that all women in the sublingual group aborted within 24 hours while only $89 \%$ in the vaginal group aborted in 24 hours.

There was no difference in success rate with reference to parity and gestational age in both the groups.
Abortion was said to be incomplete, if either whole of placenta or part of it was retained for more than three hours after expulsion of fetus or if excessive bleeding started and required evacuation. Abortion was complete in $87.8 \%$ and $81 \%$ of case in sublingual and vaginal group, respectively. This difference was not statistically significant indicating that misoprostol administered through any route is equally effective but there was a definite reduction in induction-abortion interval on sublingual administration. The various side effects observed were nausea, vomiting, pyrexia ( $\mathrm{p}<0.05)$, abdominal cramps and fatigue (Table 4). 
Table 4: Side effects.

\begin{tabular}{|llll|}
\hline & Sublingual $(\mathrm{n}=\mathbf{5 0})$ & Vaginal $(\mathrm{n}=50)$ & $\mathrm{p}$ value \\
\hline Nausea & $5(10 \%)$ & $4(8 \%)$ & NS \\
\hline Vomiting & $3(6 \%)$ & $2(4 \%)$ & NS \\
\hline Fatigue & $1(2 \%)$ & $2(4 \%)$ & NS \\
\hline Diarrhea & $1(2 \%)$ & $3(6 \%)$ & NS \\
\hline Fever & $1(02 \%)$ & $6(12 \%)$ & $\mathrm{p}<0.05$ \\
\hline Abdominal cramps & $1(2 \%)$ & $1(2 \%)$ & NS \\
\hline Total & $\mathbf{1 2}(\mathbf{2 4 \%})$ & $\mathbf{1 8}(\mathbf{3 6 \%})$ & - \\
\hline
\end{tabular}

Table 5: Subjective assessments of patients comfort to the route of administration.

\begin{tabular}{|lll|}
\hline Characteristic & Sublingual & Vaginal \\
\hline Comfortable during administration & $45(90 \%)$ & $30(60 \%)$ \\
\hline Shows discomfort during administration & $05(10 \%)$ & $20(40 \%)$ \\
\hline
\end{tabular}

Sublingual route was the most acceptable, subjective assessment of patient comfort to the route of administration was high in sublingual group (90\%) and $60 \%$ in Vaginal group. Sublingual route was convenient to administer, had less side effects, required short hospital stay.

\section{DISCUSSION}

Medical abortion is becoming more popular now days as a method of termination of pregnancy in second trimester because it is effective and technically less demanding when compared to surgical methods. ${ }^{1}$

Prostaglandin analogs are the mainstay of drugs used for this purpose. Among them, misoprostol is the most commonly used one, as it is cheap and stable at room temperature. It has been shown to be effective for second trimester termination of pregnancy. ${ }^{2}$

Misoprostol has been used to induce medical abortion by various routes of administration. Vaginal misoprostol has been shown to be more effective than oral misoprostol. However, evidence that absorption through the vaginal route is inconsistent and that the patients find vaginal administration uncomfortable has led to the sublingual route as an alternative. Oral misoprostol reaches a high peak concentration in blood very quickly before a rapid fall in plasma level. After vaginal administration there is gradual rise up to peak level and then a slow fall of level. ${ }^{3-7}$

Earlier studies by various authors ${ }^{2-7}$ comparing oral with vaginal administration with the dose regimes varying from $400-800 \mu \mathrm{g}$ at 3-hourly to 8-hourly interval have reported the success rate on vaginal administration to be in range of 56.8-99.26\%.The induction-abortion interval observed was shorter than that observed in the other studies using misoprostol by various routes or by combination of routes for second trimester termination of pregnancy (Table VI).

Recently, it has been shown that misoprostol can be administered sublingually. A pharmacokinetic study has shown that after a single dose of sublingual misoprostol, the peak concentration is achieved in a shorter time than with vaginal misoprostol. The peak concentration and bioavailability were also higher with sublingual administration. Therefore, it was postulated that sublingual route of administration might be the most effective route for administration of misoprostol by Tang et al. ${ }^{5}$

A study by Tang et $\mathrm{al}^{8}$ of 18 cases administered misoprostol $200 \mathrm{ug}$. administered 3-hourly sublingually demonstrated $100 \%$ success rate with a mean induction abortion interval $(12 \pm 3.6$ hours $)$. In the same author study, sublingual misoprostol in gestational age $<12$ weeks reported success rate of about $86 \%$. $^{9}$

Helena et $\mathrm{al}^{11}$ demonstrated that repeated administration of $400 \mu \mathrm{g}$ Misoprostol either vaginally or sublingually is an effective and acceptable option. However vaginal administration appears to produce better results among multiparous women, but more women had fever $>38 \mathrm{C}$ in Vaginal route. Shah et $\mathrm{al}^{12}$ studied role of vaginal Misoprostol for second trimester termination. They found it is effective and time saving drug for second trimester abortion. $96.6 \%$ women aborted within 20 hours. Mean Induction abortion interval was 9.43 hours with very low drug related side effects. Milani et $\mathrm{al}^{13}$ reported similar results as in our study. Dickson et $\mathrm{al}^{14}$ studied Oral, Vaginal and sublingual Misoprostol for second trimester abortion. They found that Vaginal or sublingual Misoprostol administrated after vaginal loading dose in second trimester abortion with Mifepristone is associated with a shorter time to pregnancy termination compared with an oral regime.

Table 6: Comparative study of different studies. 


\begin{tabular}{|c|c|c|c|c|c|c|c|}
\hline Author & Year & Dose schedule & $\begin{array}{l}\text { Observation } \\
\text { time (hours) }\end{array}$ & IAI (hours) & $\begin{array}{l}\text { Success rate } \\
(\%)\end{array}$ & $\begin{array}{l}\text { Dose required } \\
(\mu \mathrm{g})\end{array}$ & Side effects \\
\hline Tang OS et al ${ }^{6}$ & 2004 & $\begin{array}{l}400 \mu \mathrm{g} s / 13 \text { hourly } \\
400 \mu \mathrm{g} \text { oral } 3 \\
\text { hourly }\end{array}$ & 24 & $\begin{array}{l}13.8 \\
12\end{array}$ & 64 & & \\
\hline Guix et $\mathrm{al}^{2}$ & 2005 & $\begin{array}{l}400 \mu \mathrm{g} \text { oral }+400 \\
\mu \mathrm{g} \text { vg } 8 \text { hourly } \\
400 \mu \mathrm{g} \text { vg } 3 \text { hourly }\end{array}$ & 24 & $\begin{array}{l}25.5 \pm 24.45 \\
15 \pm 7.14\end{array}$ & $\begin{array}{l}56.8 \\
85.7\end{array}$ & & \\
\hline Tripti et $\mathrm{al}^{3}$ & 2007 & $\begin{array}{l}600 \mu \mathrm{g} v g+400 \mu \mathrm{g} \\
4 \text { hourly }\end{array}$ & 24 & $12.27 \pm 5.71$ & 99.26 & $1,638.7 \pm 322.67$ & N.V.D.F \\
\hline $\begin{array}{l}\text { Bhattacharjee } \\
\text { et } \mathrm{al}^{7}\end{array}$ & 2008 & $\begin{array}{l}400 \mu \mathrm{g} \mathrm{s} / 13 \text { hourly } \\
400 \mu \mathrm{g} \text { vg } 3 \text { hourly }\end{array}$ & 24 & $\begin{array}{l}14.1 \\
14.5\end{array}$ & $\begin{array}{l}64.03 \\
61.59\end{array}$ & & \\
\hline${\text { Caliskan et } \mathrm{al}^{4}}^{4}$ & 2009 & $\begin{array}{l}100 \mu \mathrm{g} \mathrm{s} / 12 \text { hourly } \\
200 \mu \mathrm{g} \mathrm{s} / 12 \text { hourly }\end{array}$ & 24 & $\begin{array}{l}14.75 \\
15.2\end{array}$ & $\begin{array}{l}92.6 \\
91.4\end{array}$ & $\begin{array}{l}1,274 \\
612\end{array}$ & \\
\hline Helena et $\mathrm{al}^{12}$ & 2009 & $\begin{array}{l}400 \mu \mathrm{g} \text { Sublingual } \\
\text { 3hourly } \\
400 \mu \mathrm{g} \text { intra } \\
\text { vaginally } 3 \text { hourly }\end{array}$ & 24 & $\begin{array}{l}12 \text { Hours } \\
. \mathrm{N}-14.4 \mathrm{hrs} . \\
. \mathrm{P}-11 \mathrm{hrs} . \\
. \mathrm{N}-11 \mathrm{hrs} \\
. \mathrm{P}-11.8 \mathrm{hrs}\end{array}$ & $79.8 \%$ & & $\begin{array}{l}\text { F.>38C } \\
29.9 \% \\
\text { F.>38C } \\
39.7 \%\end{array}$ \\
\hline Shah et al ${ }^{13}$ & 2010 & $\begin{array}{l}400 \mu \mathrm{g} \text { intra } \\
\text { vaginally followed } \\
\text { by } 200 \mu \mathrm{g} \text { intra } \\
\text { vaginally every } 4 \\
\text { hours }\end{array}$ & 24 & 9.43 hrs. & $96.6 \%$ & $666 \pm 315$ & $\begin{array}{l}\text { High grade } \\
\text { Fever }\end{array}$ \\
\hline \multirow[t]{2}{*}{ Milani et $\mathrm{al}^{14}$} & 2014 & $\begin{array}{l}400 \mu g \text { sublingually } \\
4 \text { hrly maximum } 5 \\
\text { doses }\end{array}$ & 24 & $\begin{array}{l}\text { Sublingual } \\
12.42\end{array}$ & $72 \%$ & & \\
\hline & & $\begin{array}{l}400 \mu g \text { Vaginally } 4 \\
\text { holy maximum } 5 \\
\text { doses }\end{array}$ & & $\begin{array}{l}\text { Vaginally } \\
14.67\end{array}$ & $76 \%$ & & \\
\hline Dickson et al ${ }^{15}$ & 2014 & $\begin{array}{l}800 \mu \mathrm{g} \text { Vaginal } \\
\text { loading dose } \\
\text { followed by } \\
400 \mu \mathrm{g} \\
\text {.Oral } 3 \text { hrly } \\
\text {.Sublingual } 3 \text { hrly } \\
\text {.Vaginal } 4 \text { hrly }\end{array}$ & 24 hours & $\begin{array}{l}\text { Oral } 9.5 \\
\text { Sublingual } \\
7.4 \\
\text { Vaginal } 7.8\end{array}$ & $\begin{array}{l}\text { Rate same in } \\
\text { sublingual } \\
\text { and vaginal }\end{array}$ & & \\
\hline \multirow[t]{2}{*}{ Modak et al $^{16}$} & 2014 & $\begin{array}{l}400 \mu \mathrm{g} \text { Sublingual } \\
\text { 3hourly }\end{array}$ & 24 & $\begin{array}{l}\text { Sublingual } \\
12.28\end{array}$ & $79.41 \%$ & & $\begin{array}{l}\text { Fever }>38 \mathrm{C} \\
26.47 \%\end{array}$ \\
\hline & & $\begin{array}{l}400 \mu \mathrm{g} \text { intra } \\
\text { vaginally } 3 \text { hourly }\end{array}$ & & $\begin{array}{l}\text { Vaginally } \\
13.11\end{array}$ & $88.24 \%$ & & $51.51 \%$ \\
\hline \multirow[t]{2}{*}{ Garg et $\mathrm{al}^{17}$} & 2015 & $\begin{array}{l}\text { Buccal } \\
400 \mu \mathrm{g} \text { loading } \\
200 \mu \mathrm{g} 6 \text { hrly }\end{array}$ & 24 & Buccal 14.64 & Buccal $80 \%$ & & \\
\hline & & $\begin{array}{l}\text { Vaginal } 400 \mu \mathrm{g} \\
6 \text { hrly }\end{array}$ & & Vaginal 11.85 & Vaginal $76 \%$ & & \\
\hline \multirow[t]{2}{*}{ Present Study } & 2013 & $\begin{array}{l}400 \mu \mathrm{g} \text { followed by } \\
200 \mu \mathrm{g} \mathrm{s} / 13 \text { hourly }\end{array}$ & 24 & $9.28+5.824$ & 98 & $9.48+389.264$ & N.V.D.F \\
\hline & & $\begin{array}{l}400 \mu \mathrm{g} \text { followed by } \\
200 \mu \mathrm{g} \\
\text { intravaginally } 3 \\
\text { hourly }\end{array}$ & & $13.60+6.17$ & 94 & $1248+415.192$ & N.V.D.F \\
\hline
\end{tabular}

Modak et $\mathrm{al}^{15}$ found induction abortion interval was shorter in sublingual group (12.28 hours), we found the similar results. Subjective assessment of comfort to the route was $88.24 \%$ in sublingual group and $54.55 \%$ in vaginal group. We also found the patients who took sublingual drug are more comfortable (90\%) while the vaginal rout the level of comfort was $60 \%$.High grade fever (>38C) was more in Vaginal group $(51.51 \%)$ as compared to sublingual group $(26.47 \%)$.

Garg et $\mathrm{al}^{16}$ found buccal route may serve an alternative to vaginal route with similar efficacy. 
In the present study, induction-abortion interval was 9.28 \pm 5.824 hours in sublingual and $13.68 \pm 6.179$ hours in intravaginal route. Shortest being only3.18 hours in 3rd gravida with 20 weeks pregnancy in sublingual and 4.28 hours in vaginal in 4th gravida of 20 weeks in vaginal route; largest being 22 hours in sublingual and 26 hours in vaginal route.

Using a high loading dose initially followed by low-dose at proper intervals to maintain sustained effect brings about effective uterine contraction and shorter inductionabortion interval. In our study, we used an initial high dose of $400 \mu \mathrm{g}$ sublingually followed by $200 \mu \mathrm{g} 3$ hourly in Group A and $400 \mu \mathrm{g}$ intravaginally followed by 200 $\mu \mathrm{g} 3$ hourly in Group B. In our study, we compared sublingual land vaginal route of administration of misoprostol and sublingual route of administration have a short induction abortion interval, better success rate and less side effects which were statistically significant as compared to vaginal route of administration. Side effects observed were minor in nature and required symptomatic management only.

Sublingual misoprostol has the advantage that it can avoid the uncomfortable and inconvenient vaginal administration. This is especially true if women start to bleed, when the absorption of the drug may be affected.

Although other studies ${ }^{1,7,14}$ have advised against carrying out caesarean myomectomy in patients with multiple fibroids, fundal intramural fibroids in the vicinity of the tubes, and patients with dense pelvic adhesions; we would clarify that the danger in multiple fibroid is significant if there are $>10$ fibroids. We also avoided caesarean myomectomy in patients with big broad ligament fibroids. The impact of this study however, maybe limited by our small sample size $(n=64)$. Further research with larger sample size could help explore our findings.

\section{CONCLUSIONS}

Misoprostol administered alone either sublingually or vaginally is an efficient drug for second trimester medical termination of pregnancy. Sublingual route is better because of its high acceptability, short induction abortion interval, more efficacies with more comfort on route of administration and lesser side effects.

\section{Funding: No funding sources}

Conflict of interest: None declared

Ethical approval: The study was approved by the Institutional Ethics Committee

\section{REFERENCES}

1. Medical Termination of Pregnancy act. MTP act (Act No. 34 of 1971) and MTP rule (1972).Available at http://mohfw.nic.in/index1.php? Accessed 10 July 2015.

2. Sedgh G, Singh H, Shah I. Induced abortion incidence and trends worldwide from 1995 to 2008. Lencet. 2012;18;379(9816):625-32.

3. Tang OS, Chan CC, Kan A, Ho PC. A prospective randomized comparison of sublingual and oral misoprostol when combined with mifepristone for medical abortion at 12-20 weeks gestation. Human Reprod. 2005;20(11):3062-6.

4. Guix C, Palacio M, Figueras F, Bennasar M, Zamora L,Coll O. Efficacy of two regimens of misoprostol for early second trimester pregnancy termination. Fetal Diagn Ther.2005;20(6):544-8.

5. Tripti N, Namrata S. Intravaginal misoprostol for termination of second trimester pregnancy. J Obstet Gynecol India. 2007;57(5):435-8.

6. Caliskan E, Doger E, Cakiroglu Y, Corakci A, Yucesoy I. Sublingual misoprostol 100 microgram versus 200 microgram for second trimester abortion: a randomized trial. Eur J Contracep Reprod Health Care. 2009;14(1):55-60.

7. Tang OS, Schweer H, Seyberth HW, Lee SW, Ho PC. Pharmacokinetics of different routes of administration of misoprostol. Human Reprod. 2002;7(2):332-6.

8. Tang OS, Lau WN, Chan CC, Ho PC. A prospective randomized comparison of sublingual and vaginal misoprostol in second trimester termination of pregnancy. BJOG 2004;111 (9):1001-5.

9. Bhattacharjee N, Saha SP, Ghoshroy SC, BhowmikS, Barui G. A randomized comparative study on sublingual versus vaginal administration of misoprostol for termination of pregnancy between 13 to 20 weeks. Aust N Z J Obstet Gynecol. 2008;48(2):165-71.

10. Tang OS, Ho PC. Pilot study on the use of sublingual misoprostol for medical abortion. Contraception. 2001;64(5):315-7.

11. Tang OS, Miao BY, Lee SW, Ho PC. Pilot study on the use of repeated doses of sublingual misoprostol in termination of pregnancy up to 12 weeks gestation: efficacy and acceptability. Hum Reprod. 2002;17(3):654-8.

12. Helena V, Gilda P, Daniel W. Comparison of Vaginal and sublingual Misoprostol for second trimester abortion: Randomized controlled equivalence trial. Human Reproduction 2009;24:10612.

13. Shah Sumant R, Tripathi J, Hiren D, Modi J. Role of Misoprostol in second trimester termination of Pregnancy. J Obstel Gynecol India. 2010;60(2):1468.

14. Forzon Milani, Seyede H, Saeedeh A. Comparison of sublingual and Vaginal Misoprostol for second trimester pregnancy termination. Journal of family and reproduction health. 2014;8:41-4.

15. Dickson, Jane E, Jenning S, Belinda G, Dohrty D. Mefipristone and oral, Vaginal or subligual Mesoprostol for second trimester abortion: A 
randomized controlled trial. Obstel Gynecol. 2014;126(6):1162-8.

16. Modak R, Dilip K, Ghosh A, Pal A. Comparative study of sublingual and Vaginal Misoprostol in second trimester induced abortion. Open Journal Obstetrics and Gynaecology.2014;4:751-6.

17. Garg G, Takker N, Sehgal A. Buccal versus Vaginal Misoprostol administration for induction of first and second trimester abortions. The Journal of Obstetrics and Gynaecology of India. 2015;65(2):111-6.

Cite this article as: Jogi SR. Comparative study of sublingual and vaginal misoprostol in second trimester induced abortion. Int J Reprod Contracept Obstet Gynecol 2015;4:1453-9. 